\title{
Tears of Reign: Big Sovereigns Do Cry
}

\author{
Kathleen Biddick
}

Hamm: What's he [Nagg] doing?

Clove: He's crying

Hamm: Then he's living ${ }^{1}$

Contemporary theorists of sovereignty and biopolitics might learn from the popular culture of zombies and its performance of the living and the living dead. ${ }^{2}$ Zombie fictions are creatively re-animating dead zones of sovereignty imagined by theorists as "bare life" (Giorgio Agamben) or the undead "flesh" of the sovereign (Santner 2011) Zombies are transubstantiating quickly: from the zombie apocalypse of Zombieland (Columbia Pictures 2009) with its Grail quest for the last Twinkie, to the now miraculous re-animation of the living dead-the subject of the novel Warm Bodies (2012) by Isaac Marion, now released as a film (Summit Entertainment 2013). Imagined as a remake of Shakespeare's Romeo and Juliet, Warm Bodies stages a love-story between the living and the living dead and in so doing questions the sovereign construction of the borders between friend (the living) and enemy (the living dead). Zombies and humans of Warm Bodies slowly re-learn language and re-enter a world of tears (such tears will become the medium of the argument that follows). Over the past fifty-years, theorists of sovereignty have spun —as feverishly as their counterparts in comics, film, TV — science-fictions of the living and the living dead. The classic study of premodern sovereignty: The King's Two Bodies: A Study in Medieval Political Theology (1957) by Ernst Kantorowicz founds the narrative. He traced how premodern jurists came to imagine the sovereign as a creature with two bodies, one living and temporal, one eternally undead. Subsequent sovereign science fictions spun from Kantorowicz-by Michel Foucault, Giorgio Agamben, Roberto Esposito, Eric Santner, to name a few authors- matter because they try to draw the line between the living and the living dead as a temporal marker: once upon a time there was the sovereign power to make die and let live (clean cuts between the living and the dead) and then came modern biopolitics, the power to make live and let die (the impasse of the living

No. 9 / 2014 special issue: bodily fluids 
and the living dead). ${ }^{4}$ Consider a recent installment of such sovereign science fictions, The Royal Remains: The People's Two Bodies and the Endgames of Sovereignty (2011). Drawing upon Kantorowicz's narrative of the king's two bodies, Eric Santner represents modernity as sovereignty's apocalyptic zombieland. The modern citizen-subject, according to his argument, is seized by a fantastic excess of alien flesh-the undead residue of the failed transference, at the time of the French Revolution, of the medieval sovereign's second body (the immortal one) into the modern body politic of the People. This paper argues that these processes of transference and periodization in contemporary theory need to be understood as sovereign border technologies. Kantorowicz drew the hard line when he presented the king's two bodies as a product of the secularizing (read also, modernizing) transference of the corporate sacramental body of the Catholic Church (corpus mysticum) into the corporate notion of juridical royal embodiment. Kantorowicz intimates that this "transfer" was what psychoanalysts would call today "transference" in that Tudor jurists fabricating the juridical fantasy of royal zombie embodiment, did so, "unconsciously rather than consciously" (19). Kantorowicz thus positioned himself fantastically as the "one who knows" classic sovereignty; scholars have been transferring to his text ever since. ${ }^{5}$ What this institutional transference has foreclosed, I argue, is the queer imbrication of classical sovereignty (to let die) and biopolitics (to make live) — the living and the living dead. ${ }^{6}$ Such temporal foreclosure results, I argue, in the fetish of modernity among the disciples of Kantorowicz. Their tracts profess their faith in biopolitics as the sign of modernity; at the very same time they must painfully disavow the disturbing evidence for untimely traumatic entanglements of classical sovereignty and biopolitics. This impasse is not much fun, as Tim Dean has pointed out in his recent essay on the "Biopolitics of Pleasure." 7 This essay asks, then, how to rethink the living and the living dead, the theoretical impasse of political theology and biopolitics, such that critique is not dismissed as "mere" historicism or, alternatively, as a misguided effort to separate out symbolic fiction from fantasy $?^{8}$ How then to argue for what I perceive as the queer untimeliness of the living and the living dead, the untimeliness of political theology and biopolitics?

\section{An Archive of Tears}

Kantorowicz opened his study of the king's two bodies with his now famous reading of William Shakespeare's tragedy, King Richard II. He concentrated exclusively on the famous deposition scene 
(Act IV) in which Richard, stripped of his regalia, calls for a mirror and shatters it upon glimpsing his reflection. According to Kantorowicz, Shakespeare's tragedy eternalized the metaphor of the king's two bodies. Subsequent theorists (notably Santner) also truncate their readings of the play at the mirror scene and argue along similar lines. But why do Kantorowicz and Santner exit the play at Act IV? There is more, I argue, to Shakespeare's performance of sovereignty in King Richard II. ${ }^{9}$ By the end of the play (the sixth scene of Act V), Shakespeare has transformed Richard into a human crying machine.

Ha; ha; keep time! how sour sweet music is,

When time is broke and no proportion kept.

So is it in the music of men's lives.

And here have I the daintiness of ear

To check time broke in a disorder'd string;

But for the concord of my state and time

Had not an ear to hear my true time broke.

I wasted time, and now doth time waste me,

For now hath time made me his numb'ring clock.

My thoughts are minutes, and with sighs they jar

Their watches on unto mine eyes, the outward watch

Whereto my finger, like a dial's point,

Is pointing still, in cleansing them from tears.

Now sir, the sound that tells what hour it is

Are clamorous groans that strike upon my heart,

Which is the bell. So sighs and tears and groans

Show minutes, hours and times. But my time

Runs posting on in Bolingbroke's proud joy,

While I stand fooling here, his Jack o' the clock.

(King Richard II-Act V-Scene 5) 
In so doing Shakespeare is staging, I argue, the temporal imbrication of classical sovereignty (to make die) and biopolitics (to make live). Richard's tears enable us to engage the question: how might an excess of tears breach the sovereign borders drawn (as we have seen) by transference and periodization of contemporary theorists? ${ }^{10}$ King Richard // offers me an archive of tears with which to explore how historians might see through sovereign scenes and see through them. ${ }^{11}$ Try this in your home archive. First, blind yourself with tears: "Deep down, deep down inside, the eye would be destined not to see but to weep. For at the very moment they veil sight, tears would unveil what is proper to the eye. ${ }^{.12}$ Archival tears offer a way into a biohistory of sovereignty, because they fold intrainter-corporeality, meaning tears are inside and outside at the same time. Tears stage scenes of fleshly encounter. ${ }^{13}$ But please be advised, my archive of tears is not, however, intended to produce a history of tears. Scholars such as Elina Gertsman, Marjory E. Lange, Kimberly Christine Patton, Tom Lutz, Peter Schwenger (to name just a few) have ably traced such genealogies. ${ }^{14}$ Nor am I trying to write a history of religious compunction and its gift of tears, since we already have good studies of such phenomena in the work of the medievalist, Sandra J. McEntire, and also in Gary Kuchar's investigation of Catholic recusant poetry of religious sorrow in early modern England, a literature of sighs and tears. ${ }^{15}$ Instead, I am asking how tears might be a media that queers the fantasy of sovereign decision and the naming of the enemy (the basic ingredients of sovereignty according to Carl Schmitt)? ${ }^{16}$

\section{So sighs and tears and groans/ Show minutes, hours and times (Act 5 Scene 5)}

When it comes to King Richard II, critical readings, as I have already noted, crescendo with the scene of the shattered mirror in Act IV. More recently, scholars have begun to claim, contra Kantorowicz, that Shakespeare was not eternalizing the metaphor of the king's two bodies in Richard II, but rather that he was desacramentalizing it. ${ }^{17}$ They argue that Shakespeare was intent on removing the corporate concept of the king's two bodies from any pretensions to an eternal register. More specifically, Gary Kuchar has recently read King Richard II as Shakespeare's intentional desacramentalizing parody of contemporary Jesuit-influenced recusant literature of devotional tears. Eternalizing, desacramentalizing - these are the binaries of counter-discourses that, I argue, miss Shakespeare's powerful staging of another political scene in Act $\mathrm{V}$ : the transformation of Richard into a human crying machine. By Act V, Scene 5, the audience already knows that assassins are on their way to Richard's 
prison cell. Meanwhile, Richard ticks away. He recounts to the audience how his heavy groans have become the mechanical gears that strike his heart which now peals the hourly chime. He observes how his hands mark each minute as they metronomically wipe the tears from his clock-face. In fabricating this human crying machine, Shakespeare mobilizes a mechanical metaphor in order to point to what he imagines as the "escapement" of sovereignty.

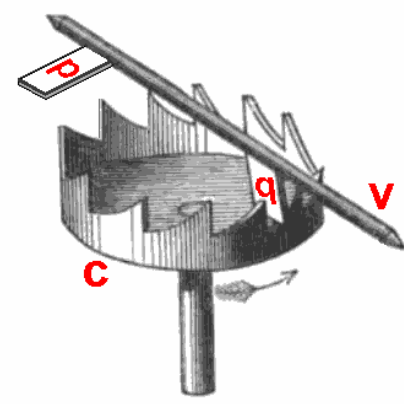

The Verge Escapement of mechanical

clock $c=$ crown wheel; $v=$ verge; $p$ and $q$

are the pennon like gears

MECHANICS OF THE OSCILLATING GEAR

CLOCK $-16^{\text {th }}$ century

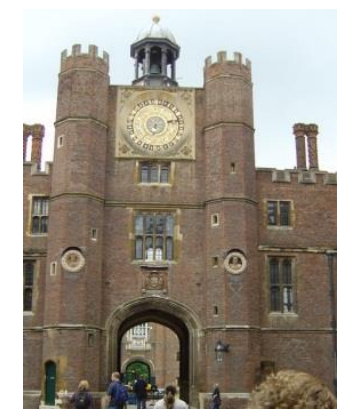

The royal mechanical clock at the Tudor

Palace of Hampton Court c. 1540,

constructed by the royal clock maker

In Elizabethan clock talk (of which geeky Shakespeare was enamored) the escapement is a generic term used to describe the mechanisms that transfer energy to an oscillating lever that produces the stepped increments registered on minute and hour hands of the clock. For Elizabethans the escapement consisted of a crown wheel (a gear shaped like a crown) driven by a weight and checked by pennon-like gears mounted on a vertical shaft, known as a verge. The verge would eventually be refined into a lever called a deadbeat. By turning the king into a human clock Shakespeare is staging sovereignty, likewise, as an oscillating lever, a verge, a deadbeat. In Act V Shakespeare uses Richard's tears as the lever. This lever oscillates discontinuously between the mortal body of the king and the imagined eternal corporate body of sovereignty. When we read this scene, we begin to wonder why 
Shakespeare devoted so much time to imagining sovereignty as a toggle, and also, why Kantorowicz read past this uncanny image of Richard as a weeping clock.

My method for exploring this conundrum is to juxtapose Shakespeare's staging of a sovereign timebomb in Act $\mathrm{V}$ with the better known scene of the shattered mirror (Act IV), so beloved by Kantorowicz. Just before Richard calls for the mirror in Act IV, he cries out to the audience that he is blinded by his tears. These blinding tears offer up to him a kind of x-ray vision-- he suddenly announces that he now is able to see himself surrounded by a pack of traitors. Hounded by this pack, Richard proceeds to gaze into the mirror and then to shatter it. I am going to pause here and ask readers to do something that might seem strange. I am asking them to pick up the pieces of this broken glass, because I think Shakespeare is using these splinters deliberately to recall images of the heated late medieval debate over the orthodoxy (or not) of the Real Presence (the transubstantiation of bread and wine into Christ's flesh and blood) in the sacrament of the Eucharist. The orthodox guarantee of the Real Presence in the Eucharist was closely bound, indeed pinned, by polemicists (as I shall unfold below) to the embodiment of the sovereign. Orthodox versions of the Real Presence and sovereignty were closely bound. By the later medieval period, theological debates over the doctrine of the Real Presence of the Eucharist revolved around optics. Heather Phillips and other scholars have noted how optics and mathematics had deeply permeated theological speculation by the fourteenth century. ${ }^{18}$ Shakespeare's much noted fascination with optics and the special effects he conjures in Richard II, need to be understood not only technically but, I argue, also theologically. A school of late medieval university scholars, conversant in optics and mathematics, rejected the doctrine of transubstantiation based on their scientific studies. John Wycliffe (1320-1384, Oxford University), for example, used the science of optics throughout his treatise, De Eucharistia (1380), in order to deny the orthodoxy of transubstantiation of the Real Presence by opening up the gap between nudum sacramentum (that is the bare bread and wine of the sacrament of the Eucharist) and res sacramenta, the virtual presence of Christ in the sacrament. Wycliffe reasoned as follows: "The body of Christ is more clear and resplendent than the sun... and at every point of the host there is the figure, Mukephi (a word he drew from Muslim optical treatises--the Arab work mukāfi', is the word for a parabola or parabolic section)." He thus imagined the host as an optical device composed of myriad paraboloid 
mirrors which focused the divine body of Christ like a burning mirror. Wycliffe used optics to refuse the binary logic of the doctrine of the real presence and called that logic a form of idolatry. In the mirror scene of King Richard II, it is as if the politics of sovereignty and Eucharistic optics become mirror images of each other. Richard, recall, had seen through his tears in Act 4 to perceive the traitors surrounding him. ${ }^{19}$ And indeed, Shakespeare's play is first and foremost a play about treason. The word treason and its variants (treason, traitor, and treachery) occur most frequently in King Richard II compared to any of his other plays. This hinging of treason with resonant images of Eucharistic optics in Act 4 seems crucial to me for an understanding of what Shakespeare is trying to do in the play regarding political theology. At this juncture, Kantorowicz's reading seems particularly unhelpful. In a book of over 500 pages in length, treason is a subject inexplicably absent from his discussion of sovereignty. He mentions treason a total of only six times. Even when discussing the play of Richard II, he merely alludes to treason, without any analysis. When he comes to his final doxological chapter devoted to Dante, whom he praised as the singular humanistic embodiment of sovereignty (selfcrowned crown and self-mitred-a kind of anamorphic image of Richard II), Kantorowicz keeps his silence regarding the stunning and leaky corporeality of treason lodged at the very heart of the Commedia. ${ }^{20}$ Readers of the Inferno will recall that at the zero-point of the Inferno, in the neighborhood (or ghetto) he dubbed Judecca, Dante encounters Satan half-trapped in the frozen lake of his tears (lesser traitors are fully frozen in the lake "like straw in glass" (Inferno XXXIV, (la dove I'ombre tutte era coperte/e transparien come festuca in vetro", II. 11-12). The emperor of the Inferno (lo 'imperador del doloroso regno" I. 28), is eternally condemned to gnawing on the traitors of Caesar (Cassius and Brutus) and on Judas (the traitor of Christ), whose bodies cram the trinity of his mouths. Neither this imperial cannibal nor the bodies on which he gorges are able to speak-and for once, Dante does not ventriloquize. ${ }^{21}$ When Dante beholds this awful sight of infernal sovereignty incorporating treason (literally), he evokes for his readers a profound sense of what Eric Santner has called "undeadness": "It was not death, nor could one call it life/Imagine, if you have the wit/ what I became, deprived of either life." (Io non mor' e non rimasi vivo/pensa oggimai per te, s'hai fior d'ingegno/qual io divenni, d'uno e d'altro privo/ (lines 25-27). ${ }^{22}$ Amidst the flap of Satan's wings and the rain of his tears, attentive readers might also hear the rustle of documents from the treason trial (1302) of Dante and his three co-defendants, whom Florentines judged guilty and condemned to 
exile. ${ }^{23}$ Kantorowicz, I speculate, disavows treason in his study of sovereignty, because the question of treason was so biographically traumatic for him. On April 20, 1933, shortly after the Nazi Party had barred Jews from civil service (Law for the Restoration of Professional Civil Service), he, who in 1930 had been appointed to a professorship in medieval history at the University of Frankfurt, wrote decisively to the Minister of Science, Art and Education to inform him forthwith that he would be suspending his summer teaching duties. ${ }^{24}$ Among the reasons he offered for this decision, was his shock that he, who had fought heroically for Germany in World War I and who had published an acclamation of a national Germany in his bestselling history, Kaiser Friedrich der Zweite (1927), was being treated like a "traitor" (Landesverräter) because of his Jewish descent. ${ }^{25}$ Treason would prove to be neuralgic for Kantorowicz throughout his career, but not so for his scholarly admirers. In Discipline and Punish (1978), Michel Foucault uncannily sutured his hectic and much celebrated opening tableaux of the execution of a regicide in Paris in 1757 with his enthusiastic (booster) endorsement of Kantorowicz's major work, The King's Two Bodies: An Essay in Political Theology which had been recently translated into French. Giorgio Agamben, another critical commentator on Kantorowicz's theory of the king's two bodies, argued for the twinning of the execution of a regicide with the killing of a homo sacer: "it does not matter from our perspective, that the killing of homo sacer can be considered as less than homicide, and the killing of the sovereign as more than homicide; what is essential is that in neither case does the killing of a man constitute an offense of homicide." ${ }^{26}$ Agamben is arguing here for the undecidability of the sovereign and homo sacer. Agamben's insight enables an understanding of how Kantorowicz unwittingly articulated such undecidability in his letter of resignation (he, a hero, is being treated like traitor and because of his Jewish ancestry he is deemed homo sacer by the new Nazi race laws). It is precisely this catastrophic undecidability that his great study of sovereignty, The King's Two Bodies (1957), forecloses. Shakespeare, in contrast, searched for the lever between royal treason and bare life, the sovereign and homo sacer, politics and theology. He is trying to rethink the zombie franchise of the late sixteenth-century. I have already noted his exploration of such a lever when he stages Richard II as a human-clock, but he also plays with this lever in Scene 4 of Act $V$ through his theatrical choices for staging the assassination of Richard. Rather than work with the commonly accepted Tudor account for Richard's demise by starvation, Shakespeare chose to use Holinshed's competing version of his death by assassination. Holinshed's account, as 
scholars have noted, deliberately echoes the medieval narrative describing the assassination of the Archbishop of Canterbury, Thomas Becket, by King Henry II. ${ }^{27}$ The bare bones of that twelfth-century story are as follows: A king wishes his adversary dead and his henchmen take matters into their own hands and execute the deed. ${ }^{28}$ In a play filled with optical illusions/allusions, the special effects of which so enamored Elizabethans, Shakespeare renders the assassination of Richard II as a kind of temporal anamorphosis. ${ }^{29}$ The audience sees the death of Richard II unfold on stage, however, when heard acoustically awry, the audience hears another temporal moment, the assassination of Thomas Becket in 1170. When the reader takes up a perspective glass to view Richard's assassination, and a perspective glass is an optical device used by Elizabethans to correct, or bring into proper perspective, the anamorphic puzzles of the type posed by painters and by dramatists, such as Shakespeare, or, alternatively, if readers physically move their vantage point, as Holbein invited viewers to do in his famous anamorphic painting of The Ambassadors, so they could view the death's head lurking there, if the reader uses these strategies to view the assassination scene, what comes into view is a surprise. The correction of Shakespeare's temporal anamorphosis reveals none other than Lanfranc of Bec (c. 1005-1089) -abbot, jurist, scholar and court prelate, justiciar and subsequently Archbishop of Canterbury under William the Conqueror. In the shadow of the Norman conquest of England, Lanfranc wrote his famous polemic on the orthodoxy of the Real Presence..$^{30}$ In his famous treatise, De corpora et sanguine Domini adversus Berengariam, composed when he moved to the newly-founded ducal monastery at Caen in 1063, Lanfranc attacked the arguments of his contemporary Berengar, who outspokenly questioned the Real Presence in the sacrament of the Eucharist (the materialization of the flesh and blood of Christ upon the words of Eucharistic consecration). Lanfranc asserted the orthodoxy that "The Flesh is the Sacrament of the Flesh (caro, videlicet carnis...sacramentum est, Lanfranc, 56)". The high stakes of this theological controversy - its conflicts between interpretation, criticism, identity, and realism - have been well studied. ${ }^{31}$ What interests me from the point of view of Shakespeare's interest in treason and the Real Presence, is how Lanfranc's treatise goes beyond the stock litany of theological polemic - (Berengar as adversary of the catholic church (catholicae Ecclesiae adversario, Lanfranc, 29), sacrilegious violator of oath (sacrilegus violator, Lanfranc, 31), heretic (esse haereticus, Lanfranc, 32) - to pioneer an accusation of treason against him (jurare perfidiam, Lanfranc, 40). Berengar, in Lanfranc's opinion, not only challenged theological orthodoxy; he also traitorously undid 
the universalism of the Catholic Church, a universalism constituted by the flesh of Christ. ${ }^{32}$ To think against this sacramental flesh is to commit treason, because, according to Lanfranc's vision, the flesh of Christ is constitutively both sacramental and sovereign. The flesh of the Eucharist, thus, for Lanfranc was both a sacramental and a sovereign problematic. His accusation brings into view both the sovereign body under threat of treason and also that of homo sacer (the one who may be killed without accusation of homicide, but who may not be sacrificed). In the gap in between the visible and the invisible, in which Berengar had meditated provocatively on the unhistorical nature of Christ's flesh, Lanfranc, instead, sutured sovereign law and in so doing paradoxically immunized universal flesh of Christ as a sovereign body politic. Thus, a biopolitics of the flesh needs to account for this "unhistorical" twining of the sacred flesh and sovereignty across the normalized divides of medieval and modern in an effort to re-conceive biopolitics of the flesh as a traumatic scene that expands and sediments as it maintains a deadly kernel, a medieval suture of flesh to sovereignty. Such a suture precludes any linear periodization of political theology and biopolitics. The suture also inverts Kantorowicz's metanarrative of political theology and sovereignty in which sacramental flesh gives way to a secularized body politic. In contrast to Kantorowicz's normalization of Shakespeare as an agent of eternalizing the king's two bodies. I have argued, instead, that the playwright stages theatrical scenes in order to expose the suture of sacramental flesh to sovereign law. The theatrical exposure does not attempt to undo sacramentality and sovereignty, but to expose their traumatic suture. But does Shakespeare stop at this stage of critique or does he go further and offer a metatheatrical critique of representation as a drive toward Real Presence, or put another way, a way of rethinking the zombie franchise of the sixteenth-century? The tears of Richard's Queen Isabella offer another archive of tears for exploring the relations between Shakespeare's critique of the sovereignty of Real Presence and his ontology of the theater. Shakespeare uses Queen Isabella to remake the widely-known medieval liturgical theater of the Easter story, known as Quem Queritis (Whom do you seek?). According to this Gospel story, Mary Magdalene discovers the empty Easter tomb and then encounters a gardener, the resurrected Christ, who asks her "Whom do you seek" and then admonished Mary Magdalene not to touch him (Noli me tangere). In his ground breaking study, entitled This is my Body: Representational Practices in the Early Middle Ages (1999), medievalist and theater-historian, Michal Kobialka has argued that changing orthodox epistemologies of the Real Presence were constitutive of medieval forms of 
representation. He tracks these changes by studying how Western Easter liturgies represented (or not) the dead body of Christ, which according to the Gospels, was absent at the empty Easter tomb. Prior to the Eucharistic crisis over the Real Presence, in the tenth- and early eleventh-centuries, no cleric ever impersonated the Risen Christ and spoke the Gospel words to Mary Magdalene. An angel-actor, clearly not Christ, would voice these words at the "stage-set" of an empty tomb. The angel addresses her tersely: Whom do you seek?/ Jesus of Nazareth. He is not here. He has risen just as it was predicted. By the end of the $12^{\text {th }}$ century, as the Church promulgated and disciplined the doctrine of the Real Presence, Kobialka shows that the body of the resurrected Christ is represented for the first time in the Easter performance of the Quem Queritis. In the late twelfth-century versions, Christ now appears on stage before Mary Magdalene in the guise of gardener. He enacts the Noli me tangere scene recounted in Gospel of John. Such a material, theatrical embodiment of the absent, resurrected Christ transformed, according to Kobialka, the medieval representational grids of space and time. What is also chilling to realize, (and this is a link that Kobialka does not really develop), is that it is these very same Quem Queritis scripts of the later $12^{\text {th }}$-century that materialize the personified body of the Jewish people, who are excoriated as deicides. Take for example, the famous play book of the abbey of Fleury, which scripts the performance of the Quem Queritis at the turn of the twelfth-century. ${ }^{33}$ What in the $10^{\text {th }}$ century counted for a three or four spare lines, had now exploded into a script of 75 lines along with stage directions. Jews are personified at the opening of the Quem Queritis script: "Alas! Wretched Jewish people, Whom an abominable insanity makes frenzied. Despicable nation". As the script unfolds, the risen (theatricalized) Christ appears to Mary Magdalene and asks her the famous question recorded in the Gospel of John: "Woman, why do you weep, Whom do you seek?" At the moment of recognition, in the famous noli me tangere scene, Christ instructs Mary Magdalene not to touch him. Kobialka links this changing ontology of theatrical embodiment to changing doctrinal epistemologies of the Real Presence at the open of the twelfth-century. The details of the epistemological change are important. Early medieval Christians had imagined the flesh of the Eucharist as a ternary flesh intertwining the corpus verum (that was the historical Christ), corpus mysticum (that was the Eucharist) and corpus Christi (that was the Church). With the promulgation of the doctrine of transubstantiation the sacramental flesh was reduced to a binary. The corpus verum dropped out; the Universal Church came to be regarded as the corpus mysticum; the corpus Christi became the Eucharist. This chiasmic 
reduction from a ternary to binary epistemology resulted in the (death) drive to represent the absent resurrected Christ theatrically and, as art historians tell us, in other media, witness, for example, the eruption of human forms in Romanesque sculpture. The monumental Romanesque building program at ducal abbey at Caen, over which Lanfranc presided from 1063-1070, just at the inauguration of the orthodoxy of the Real Presence, featured only one capital sculpted with a human form. Within one generation, as that orthodoxy became the subject of disciplinary enforcement, sculpted humanoid forms would come to populate Romanesque capitals, as well as monumental porches of those churches. ${ }^{34}$ Kobialka offers a trenchant insight into these new representational modes of embodiment "Whereas in the corporeal and mystical approaches [that is, ternary], the body of Christ was silent, now the silent body was to speak the language of theological pedagogy that delimited the space of representation by consolidating the structures of belonging." ${ }^{35}$ This binary sacramental flesh profoundly reorganized the temporal and spatial coordinates of medieval representation and forced a dominant gaze to organize itself around a body that is forced to materialize within theatrical space.

\section{Fresh again, with true love's tears (King Richard V/1/10)}

So what does Shakespeare's politics of the scene have to do with Kobialka's genealogy of changing forms of medieval representation? Kobialka imagines the Renaissance stage as the teleological endpoint of such theatrical pedagogy involved in the coerced materialization of the Real Presence in the form of an actor. I disagree with Kobialka's teleology, and I think Shakespeare would too. And now let me explain why. Shakespeare rewrote the medieval Easter Quem Queritis trope self-consciously in several of his plays, and, most notably in King Richard II in order to unpin sovereignty from the Real Presence, to re-imagine the boundaries of the living and living dead configured in the eleventh century. In Act III, scene 4, Richard II, Shakespeare opens his re-staging of the Quem Queritis trope. ${ }^{36}$ Richard's queen, Isabella, still uninformed of her husband's recent capture by his usurper, Bolingbroke, but fearing the worst, seeks respite in a garden accompanied by her attendants. Shakespeare sets the stage reminiscent of the medieval horotolanus scene of the Quem Queritis in which Mary Magadalene and the two other Mary's hasten to the tomb before which the apostles John and Peter puzzle over the absence of Christ's body and the presence of the discarded shroud. Mary then encounters a gardener who reveals himself to her as the resurrected Christ. In Shakespeare's scene the tidings of the gardener 
to Isabella (staged as a kind of Mary Magdalene) are not about resurrection. Instead, the gardener informs the queen of a kind of anti-transfiguration in which Richard is described as "depressed he is already/ and disposed 'tis doubt he will be" (Act III.4. 68/69). The scene closes with the gardener's promise to plant a memorial bush of rue on the spot where the tears of the weeping queen fell. In this pseudo- Quem queritis scene, Shakespeare thus imagines the tears of Magdalene/lsabella not as redemptive, but as memorial, and in so doing, he inters, but not disrespectfully, important representational strands of twelfth-century versions of the Quem Queritis trope that had constituted themselves, as I have already noted, around the materialization of the absent body.Shakespeare is rewriting the garden scene. But, are his moves those of desacralization as Gary Kuchar has argued in his own intriguing reading of these Quem Queritis stagings in Richard II? To ponder this question, let us see how Shakespeare further pursues staging the Quem Queritis scene in Act V, Scene 1. By this moment in the play, Richard has already deposed himself and is about to wend his way through the streets of London to the Tower. His queen and her attendants await him along the parade route. Isabella is now cast as Mary Magdalene on the verge of encountering the resurrected Christ. She wishes, on catching sight of him, that she, like the Magdalene, could wash Richard "fresh again with true love tears" (Act V/1/10) as Mary Magdalene has once washed the feet of Christ with her tears. But Shakespeare's staging of their encounter inverts, once again, aspects of the medieval Quem Queritis script. Isabella sees in Richard not a resurrected body, as Mary Magdalene did in the Gospel stories, but, instead, a zombie: "Thou map of honour, thou King Richard's tomb" (5/1/12). Richard turns to Isabella and speaks the word of Christ addressed to the Magdalene on Easter morning: Noli flere (do not weep): "Join not with grief, fair woman (Act V.1.16)". Shakespeare then crosses out the subsequent scene of Noli me tangere, although it is a scene that he did know well and staged in All's Well that Ends Well. Importantly, in Richard II, Shakespeare does not defer the touch refused by the Gospel Noli me tangere; instead, he has Richard and Isabella kiss before their final separation. Their substitution of a kiss for the refusal of touch (Noli me tangere) has been read as a parodic sign of desacralization on Shakespeare's part. But, I ask, do we mis-recognize this kiss as a touch? Does this kiss touch upon something different? Richard speaks: "One kiss shall stop our mouths, and dumbly part" (5/1/95). Shakespeare takes this image, "stop our mouths" from the New Testament, namely, Paul's Epistle to Titus (1.11), where Paul rails against what he called the "circumcision party" in Corinth and uses an 
imperative Greek form of the verb, epistomizo, meaning to stop the mouth. It is the word used in Greek to put the bit in the horse's mouth, to insert the mouthpiece on the flute. Shakespeare uses the phrase several times in his plays with menacing connotations. Thus, though Richard and Isabella do touch, indeed, kiss each other on the mouth, it is kiss of violence, a silencing, a touch that is not a touch-a touch that produces untouchability. I think Shakespeare is doing two things here. First, I think he is deliberately unstaging the risen Christ in this scene in order to open up the third term of the Quem Quaeritis and that term was the absent, silent body of the resurrected Christ. The unspoken words of the Noli me Tangere in Act V, scene 1 honor the silent body of the absent Christ without forcing that body "to speak the language of theological pedagogy that delimited the space of representation by consolidating the structures of belonging." By staging a touch that does not touch, the kiss as a form of torture, that stops the mouth, Shakespeare, I think is not desacralizing nor resacralizing, but he is asking us all to reconsider a post-Real Presence in which the living dead do not underwrite the living. Just as in Warm Bodies, and its staging of a love between the living and the living dead, Shakespeare asks us to think again what is touch, what is absent silence, what is the Real Presence, then and now. How can we imagine a quickening of the dead zones of contemporary citizenship? The dramatist not only re-poses the Gospel question: Whom do you seek? He asks, too, who decides? To weep or not to weep, the living and the living dead?

\section{Notes}

1 The play, Endgame, by Samuel Beckett was first performed April 3, 1957, one month after Ernst Kantorowicz published his classic The King's Two Bodies: A Study in Medieval Political Theology (Princeton, NJ: Princeton University Press, 1957). It is useful to hold the two texts together. Samuel Beckett, Endgame: A Play in One Act (London: Faber and Faber, 1958); accessible (November 12, 2012): http://samuel-beckett.net/endgame.html.

${ }^{2}$ Modeled on Donna Haraway's famous Cyborg Manifesto see, Sarah Juliet Lauro and Karen Embry, "A Zombie Manifesto: The Non-Human Condition in the Era of Advanced Capitalism", Boundary 2, 35 (2008), pp. 85-108. Deborah Christie and Sara Juliet Laura, eds. Better off Dead: The Evolution of the Zombie as Post-Human (New York: Fordham University Press, 2011). 
${ }^{3}$ Giorgio Agamben, Homo Sacer: Sovereign Power and Bare Life, translated by Daniel Heller-Roazen (Palo Alto: Stanford University Press, 1998), p. 104; Eric L. Santner, The Royal Remains: The People's Two Bodies and the Endgames of Sovereignty (Chicago: University of Chicago Press, 2011).

${ }^{4}$ Kantorowicz, The King's Two Bodies. This essay engages in debates raised by the recent publications by Eric L. Santner and Graham Hammill which revisit in contrasting ways the question of political theology: Eric L. Santner, The Royal Remains; Graham Hammill, The Mosaic Constitution: Political Theology and Imagination from Machiavelli to Milton (Chicago: University of Chicago Press, 2012). Hammill's study offers a persuasive critique of the corporeal literalization of the metaphor of the king's two bodies. Likewise Jacques Lezra rethinks the politico-philosophic conditions of present democracy by questioning the incarnations of the king's two bodies: Wild Materialism: The Ethic of Terror and the Modern Republic (New York: Fordham University Press, 2010). Also my critique of sovereignty and messianic thinking: "Dead Neighbor Archives: Jews, Muslims and The Enemy's Two Bodies" in Political Theology and Early Modernity, ed. Julia Reinhard Lupton and Graham Hammill (University of Chicago Press, 2012): pp. 124-142. These studies engage the so-called classics of political theology: Carl Schmitt, Political Theology: Four Chapters on the Concept of Sovereignty, trans. of Politisches Theologie (1922) by George Schwab (Chicago: University of Chicago Press, 1985), Walter Benjamin, The Origin of the German Tragic Drama, trans. By John Osborne (London, 1977), Samuel Weber, "Taking Exception to Decision: Theatrical-Theological Politics. Walter Benjamin and Carl Schmitt," in Walter Benjamin 1892-1940 zum 100. Geburtstag, ed by Uwe Steiner (New York: Peter Lang, 1992), pp. 123-138, Giorgio Agabmen, Homo Sacer; Michel Foucault, The History of Sexuality, vol. 1. An Introduction, trans. Robert Hurley (New York: Random House ,1978), 145; Michel Foucault, Society Must Be Defended: Lectures at the College de France 1975-76, ed. by Mauro Bertani and Alessandro Fontana, trans. by David Macey (New York, 2003), pp. 239-263 and also his Discipline and Punish: Birth of the Prison, trans. By Alan Sheridan (New York: Random House, 1977). Roberto Esposito, Bíos: Biopolitics and Philosophy, translated by Timothy Campbell (Minneapolis: University of Minnesota Press, 2008).

${ }^{5}$ For a study of Kantorowicz sensitive to these issues of institutional transference see Alain Boureau, Kantorowicz: Stories of a Historian, translated by Stephen G. Nichols and Gabrielle M. Spiegel (The Johns Hopkins University Press, 2001). Kathleen Davis points to the traumatic medievalisms of sovereignty. For insight into this uncanny persistence of sovereignty in these purported acts of deconstruction see her Periodization and Sovereignty: How Ideas of Feudalism and Secularization Govern the Politics of Time (University of Pennsylvania Press, 2008). For a review see http://hdl.handle.net/2022/6531 (accessed November 5, 2012)

${ }^{6}$ Staked out in discursive terms: Kathleen Biddick, "Unbinding the Flesh in the Time that Remains: Crusader Martyrdom, Then and Now," GLQ 13 (2007): pp. 197-225 and Biddick, "Dead Neighbor Archive". 
${ }^{7}$ Tim Dean, "The Biopolitics of Pleasure," South Atlantic Quarterly, 111 (Summer 2012): 477-495.

${ }^{8}$ The periodization of sovereignty has unfortunately closed down lively ways of re-imagining Lacanian psychoanalysis and temporality. For inspiration in this creative effort see the reconfigurative work of the Lacanian psychoanalyst and artist, Bracha L. Ettinger, The Maxtrixial Boderspace (with a Foreward by Judith Butler) (Minneapolis MN: University of Minnesota Press, 2006), p. 167. Her revisions of Lacanian psychoanalysis can productively open the boundaries between creaturely life and animal life defended by Eric L. Santner (see footnote 1). I also have in mind the rich critique of temporalities engaged by queer theorists: Carolyn Dinshaw, "Touching on the Past," in The Boswell Thesis: Essays on Christianity, Social Tolerance, and Homosexuality, ed. Mathew Kuefler (Chicago: University of Chicago Press, 2006), pp. 57-73; Elizabeth Freeman, Time Binds: Queer Temporalities, Queer Histories (Durham NC: Duke University Press, 2010); Carla Freccero, Queer/Early/Modern (Durham NC; Duke University Press, 2006); Biddick, "Unbinding the Flesh"; Michael Uebel, "Opening Time: Psychoanalysis and Medieval Culture," in Cultural Studies of the Modern Middle Ages, edited by Eileen A. Joy, Myra J. Seaman, Kimberley K. Bell and Mary K. Ramsey (New York: Palgrave, 2007), pp. 269-74. The question of the medieval as the unconscious of contemporary theory grows more pressing and is taken up in the issue of the Minnesota Review, no. 80 (April 2013), ed. Andrew Cole. On the same problem: Bruce Holsinger, The Premodern Condition: Medievalism and the Making of Theory (University of Chicago Press, 2005) and Andrew Cole and D. Vance Smith, eds, The Legitimacy of the Middle Ages: On the Unwritten History of Theory (Duke University Press, 2010) and my review: http://hdl.handle.net/2022/9063 (accessed November 5, 2012).

${ }^{9}$ Citations from King Richard II are taken from The Norton Shakespeare, $2^{\text {nd }}$ edition, general editor, Stephen Greenblatt (New York: W.W. Norton Company, 2008).

${ }^{10}$ Richard II was rumored to be "sodomitical" in his lifetime and Lancastrian propaganda emplotted his alleged sodomitical perversity to justify his deposition after the fact: Sylvia Federico, "Queer Times: Richard II in the Poems and Chronicles of Late Fourteenth-Century England," Medium Aevum, 79 (2010): 25-46. Judith Brown offers a beautiful meditation on Richard's queerness in her essay, "Pretty Richard (in Three Parts)", ShakesQueer: A Queer Companion to the Complete Works of Shakespeare, ed. By Madhavi Menon (Durham NC: Duke University Press, 2011), pp.286-301.

${ }^{11}$ David Michael Kleinberg-Levin, Sites of Vision: The Discursive Construction of Sight in the History of Philosophy (Boston: MIT Press, 1997), p. 197.

12 Jacques Derrida, Memoirs of the Blind: The Self-Portrait and Other Ruins, trans. By Pascale-Anne Brault and Michael Naas (University of Chicago Press 1993)., p. 126 and the beautiful meditations of John D. Caputo in The Prayers and Tears of Jacques Derrida (Bloomington: Indiana University Press, 1997) and Anais N. Spitzer's chapter on tears in her study, Derrida, Myth and the Impossibility of Philosophy (New York: Continuum, 2011), pp. 24-45. 
13 Paul A. Kottman, A Politics of the Scene (Stanford University Press, 2008). Kottman urges that students "reorient our understanding of politics by making the dramatic scene (or, better, scenes) a fundamental category of political life." (p. 7).

${ }^{14}$ Two of my favorite essays in the bibliographic vale of tears: Lance Duerfahrd, "Afterthoughts on Disability: Crying at William Wyler's Best Years of Our Lives," in On the Verge of Tears: Why the Movies, Television, Music, Art, Popular Culture, and the Real World Make us Cry, ed. by Michele Byers and David Lavery (Newcastle upon Tyne: Cambridge Scholars Publishing, 2010), pp. 50-66; Éamonn Dunne and Michael O'Rourke, "Miller's Idle Tears, " (forthcoming). For an introduction to a bibliography on tears, see the following studies: Elina Gertsman, ed. Crying in the Middle Ages: Tears of History (New York: Routledge, 2012); Marjory E. Lange, Telling Tears in the English Renaissance (New York: Brill, 1996); Tom Lutz, Crying: The Natural and Cultural History of Tears (New York: Norton, 1999); Kimberley Christine Patton and John Stratton Hawley, Holy Tears: Weeping in the Religious Imagination (Princeton University Press, 2005); Peter Schwenger, The Tears of Things: Melancholy and Physical Objects (University of Minneapolis Press, 2006) and for discursive reflections: Slavoj Žižek, The Fright of Real Tears: Krzysztof Kieslowski Between Theory and PostTheory (London: British Film Institute, 2001). I have also benefited from this beautiful essay: Annika Thiem, "Adorno's Tears: Textures of Philosophical Emotionality," MLN 124 (2009): pp. 592-613;

15 Sandra J. McEntire, The Doctrine of Compunction in Medieval England: Holy Tears (Lewiston, NY: Mellen Press, 1990); Gary Kuchar, The Poetry of Religious Sorrow in Early Modern England (Cambridge University Press, 2008).

${ }^{16}$ The prominent German legal scholar of sovereignty, Carl Schmitt, famously argued for these two criteria of the sovereign in his diptych of works: Political Theology: Four Chapters on the Concept of Sovereignty, trans. of Politisches Theologie (1922) by George Schwab (Chicago: University of Chicago Press, 1985), and The Concept of the Political, trans. of Der Begriff des Politischen by George Schwab (Chicago: University of Chicago Press, 1996).

${ }^{17}$ For reflections in desacramentalization see Regina Mara Schwartz, Sacramental Poetics at the Dawn of Secularism (Stanford University Press, 2008); Kuchar, Poetry of Religious Sorrow and also his Divine Subjection: The Rhetoric of Sacramental Devotion in Early Modern England (Duquesne University Press, 2005); David Womersley, Divinity and State (Oxford University Press, 2010).

${ }^{18}$ See the important essay by Heather Phillips, "John Wyclif and the Optics of the Eucharist", in From Ockham to Wyclif, edited by Anne Hudson and Michael Wilks Studies in Church History, Subsidia 5 (Oxford: Basil Blackwell, 1987), pp. 245-258, citation of Wyclif appears in Phillips, p. x.; David Aers, Sanctifying Signs: Making Christian Tradition in Late Medieval England (Notre Dame IN: University of Notre Dame Press 2004), pp. 53-66; Dallas G. Denery II, Seeing and Being Seen in the Later Medieval World: Optics, Theology and Religious Life (New York: Cambridge University Press, 2005). 
${ }^{19}$ Christopher Pye richly reflects on the theatricality of grief and treason and invites us to think of tear blots as well as inky blots, "The Betrayal of the Gaze: Richard II," in his The Regal Phantasm: Shakespeare and the Politics of the Spectacle (New York: Routledge, 1990), pp.82-105. My analysis draws together theological debates over the Real Presence and the question of treason.

${ }^{20}$ Intimates of the Stefan George circle (of whom Kantorowicz was a loyal member in the 1920s to the death of Stefan George in 1933) might have read such acclamations of Dante as a secret tribute to their Master, Stefan George, who was known to costume himself as Dante in laurels, for photographs and discussion. See Robert E. Norton Secret Germany: Stefan George and His Circle (Ithaca NY: Cornell University Press, 2002). The text of Inferno Canto 34 may be found conveniently at the Princeton Dante Project: http://www.princeton.edu/dante. See John A. Scott, "Treachery in Dante," in Studies in the Italian Renaissance: Essays in Memory of Arnolfo B. Ferruolo, (Naples: Società Editrice Napoletana, 1985), pp. 27-39

${ }^{21}$ Sylvia Tomasch, "Judecca, Dante's Satan and the Dis-placed Jew", in Text and Territory: The Geographical Imaginary in the European Middle Ages, ed. by Sylvia Tomasch and Sealy Gilles (Philadelphia: University of Pennsylvania Press, 1998), 247-267.

${ }^{22}$ Eric Santner, On the Psychotheology of Everyday Life: Reflections on Freud and Rosenzweig (Chicago: University of Chicago Press, 2001), pp. 19.

${ }^{23}$ Randolph Starn, Contrary Commonwealth: The Theme of Exile in Medieval and Renaissance Italy (Berkeley: University of California Press, 1982). Starn lists the seven counts against Dante and three named co-defendants brought forth by the court (pp. 70-71). They range from forgery (tampering with public documents) to incitement of rebellion. Neither Dante nor his co-defendants appeared in court or responded to the subsequent bans declared against them. On 27 January 1302, the court, following the legal fiction of ficta litis contestatio (simulated trial) sentenced them to exile for two years. On the 10 March 1302 the court sentenced Dante and fourteen others under communal ban to death by fire. These legal proceedings expose the vertiginous convergence of accusations of forgery, incitement to rebellion (treason) and ban, since those banned from the commune were regarded as the "enemy" (hostes).

${ }^{24}$ The literature on Kantorowicz is copious also and I cite here a insightful starting point: Boureau, Kantorowicz: Stories of a Historian.

${ }^{25}$ The text of this letter is reproduced in Eckhart Grünewald, Ernst Kantorowicz und Stefan George: Beiträge zur Bibliographie des Historikers bis zum Jahre 1938 und zu seinem Jugendwerk "Kaiser Friedrich der Zweite" (Wiesbaden: Frankfurter Historische Abhandlungen, 1982), pp. 114-15. 
${ }^{26}$ Foucault, Discipline and Punish, p. 28; Agamben, Homo Sacer, p. 102. Agamben comments directly on the King's Two Bodies in his State of Exception, translated by Kevin Attell (Chicago: University of Chicago Press, 2005), pp. 83-84.

${ }^{27}$ Lister M. Matheson, "English Chronicle Contexts for Shakespeare's Death of Richard II," in From Page to Performance: Essays in Early English Drama, edited by John A. Alford (East Lansing MI: Michigan State University Press, 1995), pp. 195-219.

${ }^{28}$ Victor Houliston, "Thomas Becket in the propaganda of the English Reformation," Renaissance Studies, 7 (1993): pp. 43-70; A.G. Harmon, "Shakespeare's Carved Saints," Studies in English Literature 45 (2005): 315-331; Robert E. Scully, "The Unmaking of a Saint: Thomas Becket and the English Reformation," Catholic Historical Review, 86 (October 2000): pp. 579-602.

${ }^{29}$ The OED defines anamorphosis as follows: "a distorted projection or drawing of anything, so made that when viewed from a particular point, or by reflection from a suitable mirror, it appears regular and properly proportioned." Pye, "Betrayal of the Gaze"; Allan Shickman, "The 'Perspective Glass' in Shakespeare's Richard II," Studies in English Literature, vol. 18 (Spring 1978): pp. 217-28 and ibid, "'Turning Pictures' in Shakespeare's England," The Art Bulletin, 59 (March 1977): pp. 67-70; Ernest Gilman, The Curious Perspective: Literary and Pictorial Wit in the Seventeenth Century (Yale University Press, 1978), pp. 88-127; Robert M. Schuler, "Magic Mirrors in Richard II," Comparative Drama 38 (2004), pp. 151-172; Alison Thorne, Vision and Rhetoric in Shakespeare: Looking Through Language (New York: St. Martin's Press, 2000).

${ }^{30}$ An English translation of Lanfranc's Liber de corpora et sanguine Domini (c. 1063) may be found in The Fathers of the Church. Medieval Continuation, vol. 10, translated by Mark G. Vaillancourt (Catholic University of America, 2009); hereafter called Lanfranc. Vaillancourt keys his English translation to the Latin text of the Patrologia Latina 150: pp. 407-442. For a concise and insightful summary of the Berengar debate see Jean de Montclos, "Lanfranc et Bérengar: les origines de la doctrine de la Transsubstantiation," in Lanfranco de Pavia e L'europa del secolo XI, edited by Giulio D'Onofrio (Italia Sacra: Studi e Documenti di Storia Ecclesiastica. Vol. 51 (Rome: Herder Editrice e Libreria, 1993), pp. 297-326. The citation is from Lanfranc, p. 56. See also, Charles M. Radding and Francis Newton, Theology, Rhetoric, and Politics in the Eucharistic Controversy 1078-1079: Alberic of Monte Cassino against Berengar of Tours (Columbia University Press, 2003).

${ }^{31}$ The literature is copious and I cite here a few exemplary studies: Brian Stock, The Implications of Literacy: Written Language and Models of Interpretation in the Eleventh and Twelfth Centuries (Princeton University Press, 1983), pp. 252-314; Michal Kobialka, This is My Body: Representational Practices in the Early Middle Ages (University of Michigan Press, 1999); Brigitte Miriam Bedos-Rezak," Medieval Identity: A Sign and a Concept," American Historical Review (December 2000): 1489-1533; David Aers and Sarah Beckwith, " Eucharist," in Cultural Reformations: Medieval and Renaissance in 
Literary History, ed. Brian Cummings and James Simpson (Oxford University Press, 2010), pp. 15316; Amy Nelson Burnett, "The Social History of Communion and the Reformation of the Eucharist," Past and Present, 211 (2011): pp. 77-119.

${ }^{32}$ For a recent consideration on Lanfranc on universalism (his resurrection of Augustinian themes) see Patrick Healy, "A Supposed Letter of Archbishop Lanfranc: Concepts of the Universal Church in the Investiture Contest," English Historical Review, Vol. CXXI, no. 494 (December 2006): pp. 1385-1407.

${ }^{33}$ The text of this Easter play is recorded in both Latin and English in David Bevington, Medieval Drama (Boston: Houghton Mifflin, 1975), pp. 39-44. See also Thomas P Campbell and Clifford Davidson (eds), The Fleury Playbook: Essays and Studies. Early Drama, Art, and Music Monograph Series no. 7 (Kalamazoo Ml: Medieval Institute Publications, 1985). Theresa Tinkle," Jews in the Fleury Playbook," Comparative Drama 38 (2004), pp. 1-38. Shakespeare played with the "quem queritis" trope in several plays as Cynthia Lewis outlines, "Soft Touch: On the Renaissance Staging and Meaning of the 'noli me tangere' Icon," Comparative Drama, 36, (2002): pp. 53-73.

${ }^{34}$ For a major study of the building program at Caen and discussion of its sculpture from the first building phases see, Eric Gustav Carlson, "The Abbey Church of Saint-Etienne at Caen in the Eleventh and early Twelfth Centuries," (University Microfilms, Yale University Ph.D., 1968), pp. 296.

${ }^{35}$ Michal Kobialka, This is My Body: Representational Practices in the Early Middle Ages (Ann Arbor Ml: University of Michigan Press, 1999), p. 157. My argument disagrees with that of Wolfgang Iser who wrote: "In this context the persona appears as a kind of empty space, and the filling of this space is what constitutes the thrust of the play" in his Staging Politics: The Lasting Impact of Shakespeare's Histories, trans. By David Henry Wilson (New York: Columbia University Press, 1993). Instead, I am arguing that Shakespeare attempts to keep the empty space open and uses the sense of seeing through tears to do so.

${ }^{36}$ Kuchar, The Poetry of Religious Sorrow, construes Shakespeare's "Quem Queritis" scene as a parody and a desacralizing move, pp. 48-53. To complicate the performance of Queen Isabella, recall her biopolitics as a presumably Virgin Queen: born November 9, 1389; wed to Richard II at the age of 7 (1 November, 1396); separated at age 10 by his abdication and imprisonment (1399) and then widowed by the ripe age of 11: Helen Ostovich, "'Here in this garden': The Iconography of the Virgin Queen in Shakespeare's Richard II," in Marian Moments in Early Modern British Drama, ed. By Regina Buccola and Lisa Hopkins (Burlington VT: Ashgate, 2007), pp. 21-34. The scene of the kiss also reminds us that both Anglican and continental Protestant Eucharistic liturgies removed the "kiss of peace" offered in the congregation after the Communion: Craig Koslofsky, "The Kiss of Peace in the German Reformation," in The Kiss in History, ed. by Karen Harvey (Manchester: Manchester University Press, 2005), pp. 18-35. 